\title{
EFFECT OF BENZENE ON BLOOD PARAMETERS OF MALE MICE
}

\section{Sami Al-Maliki* Damia Kasim Sukar** Khalid Al-Fartosi***}

*Department of Biology,College of Education,University of Basrah,Iraq.

**Department of Biology,College of Science,University of Basrah,Iraq.

***Department of Biology,College of Education,University of Thi-Qar,Iraq.

\section{Summary :-}

Super and ordinary benzene were used to examine the effect of benzene on blood parameters of male mice. Three stages with five treated groups were used. The first stage was after the end of injection period. The second stage was after 45 days from the end of injection period. Third stage was after 90 days from the end of injection period. I.P. injection was used. The results of this study indicate the decline of all blood parameters with more reduction in the mice that were experimented directly after the third injection ( first stage) .Such reduction seems to be slight in animals experimented on 45 days after the last injection (second stage) and little or absent in these were experimented 90 days after the last injection (third stage ).

\section{Introduction}

Benzene which is a volatile, colorless and highly flammable liquid, was first discovered in 1925 by Michael Faraday, who isolated it from a liquid condensed from compressed oil gas (Gist \&Burg,1997). People are exposed to benzene mainly through the inhalation of contaminated air particularly in areas of heavy automobile traffic and around gasoline (petrol) stations and other facilities for storage and distribution of benzene (ATSDR , 1991). The metabolism of benzene is required for expression of benzene toxicity, and the evidence has been summarized in several reviews ( Ross, 1996;Snyder \& Hedli, 1996 ; ATSDR , 1997). Many studies by Sabourin, et al. $(1987,1988,1989$, 1992) showed that differences in species, route of exposure and dosing regimens would effect the disposition and metabolic fate of benzene. The effect of species differences was evidenced by the fact that mice have a higher minute volume per kg body weight than rats. This caused the blood concentration of benzene to reach equilibrium more quickly in mice than in rats, but the steady-level in blood was not influenced (Sabourin et al. ,1987).

Benzene was first identified as a hematological toxicant in the nineteenth century .Experience since that time has amply confirmed the ability of benzene to destroy bone- marrow precursor cells 
responsible for the production of mature circulating blood cells in humans. Similar effects are noted in the many species of laboratory animals that have been experimentally exposed to benzene (Goldstein \& Witz,2000).As in experimental animals, the primary target organ of benzene that results in hematological changes is the bone marrow. It has been suggested the cells at highest risks are the rapidly proliferating stem cells (Marcus,1990). Benzene produces is pancytopenic and aplastic effects through damage to precursors within the marrow by its metabolites.

Benzene induced hematoxicity results from short - term as well as long - term exposure to the chemical. Early general toxicity studies reported leucopenia in dogs and fatal anemia in mice exposed to $600 \mathrm{ppm}(1917 \mathrm{mg} / \mathrm{m3})$ of benzene for 12-15 days ( Hough \& Freeman, 1944 ), changes in bone marrow histopathology or leucopenia in rats, guinea pigs, and rabbits exposed to 80-85 $\mathrm{ppm}$ ( $256-272 \mathrm{mg} / \mathrm{m3}$ ) of benzene for 23-187 exposures ( Wolf et al.,1956), and leucopenia in rats exposed to $61 \mathrm{ppm}$ ( $195 \mathrm{mg} / \mathrm{m3})$ of benzene for 2-4 weeks or to $44 \mathrm{ppm}$ ( $141 \mathrm{mg} / \mathrm{m3}$ ) for $5-8$ weeks ( Deichmann et al. 1963 ).Benzene is an established cause of acute nonlymphocytic leukemia, aplastic anemia, and benzene poisoning (hematotoxicity) and may cause other lymphohematopoietic malignancies and related conditions ( Hays et al.,2001, Zhang et al. 2002 ).

The present study aims to investigate the effects of super and ordinary benzene exposure blood parameters of male mice.
2. Materials and Methods

Super and ordinary benzene was used to examine the effect of benzene on blood parameters of male mice ( Mus musculus L.).

\subsection{Animal husbandry}

The laboratory albino Balb/C mice were brought from drug and serum center/Baghdad , Al-Razi center/Baghdad and central health laboratory/Baghdad. The mice were bred and housed in the animal house of the Biology Department/ College of Education /Basrah University .The technique used in breeding and maintaining the mice was based on that described by Jawad (1997).

\subsection{Animal house}

The mice colonies were housed in a separate room. Animals were maintained in a light-controlled room ( white fluorescent light on from 6.00$1800 \mathrm{hr}$. and darkness for the rest of the day) and at a temperature of (25+- 3C) through the year. The control of light and temperature are necessary as it is well known that both light and temperature influence gonadal function in wild and domesticated rodents (Clark \& Kennedy,1967;Alleva et al .,1968;Ray et al .,1968).

Mice were kept in opaque polypropylene cages measuring $(30 * 12 * 11) \mathrm{cm}$ with stainless lids (North Kent Plastic ,Kent, U.K.),supplied with sawdust substrate which were changed weekly. Food and water were supplied add libitum.

The mice were divided into five groups each group contain ten animals $(n=10)$ as following :

1- The control group was treated with physiological saline (0.9\% $\mathrm{NaCl})$. 
2- The first treated group was treated with $0.2 \mathrm{ml} / \mathrm{kg}$ body weight of super benzene.

3- The second group was treated with $0.1 \mathrm{ml} / \mathrm{kg}$ body weight of super benzene. 4- The third treated group was treated with $0.2 \mathrm{ml} / \mathrm{kg}$ body weight of ordinary benzene.

5- The fourth treated group was treated with $0.1 \mathrm{ml} / \mathrm{kg}$ body weight of ordinary benzene.

Male mice received three intrapretoneal injections (I.P.) throughout this study by using of micro liter syringe .These injections conducted over three intervals as following:-

1- First injection conducted at 8-9 weeks of old (Zero day).

2- Second injection conducted five days after the first injection (fifth day).

3- Third injection conducted ten days after the first injection (tenth day).

\subsection{Effect of benzene on hematological tests of male mice}

One hundred fifty intact male used in these tests .These males were divided into three stages given (as shown below) with the same groups (for each stage) and the same doses, route and times of injection [see 2.2. ].

Hematological parameters were measured as following:-

1- After third injection (10 days after the first injection)(first stage).

2- After forty -five days from the last injection(Second stage).

3- After ninety days from the last injection (Third stage).

Blood samples of male mice in all groups and stages, were collected from heart by using $1 \mathrm{ml}$ syringe after drug by ether and removal of external skin.
Blood samples were put in plastic tubes containing (EDTA) as anticoagulant.

All blood parameters (blood picture) were performed based on the methods ,which are described by (Schalm et al.,1975;Baker \&Silverton ,1976; Coles,1986).The blood parameters which were studied in this study included:-

1- Red blood corpuscles count (R.B.C .count).

2- White blood corpuscles count (W.B.C. cont).

3- Hemoglobin concentration (Hb.).

4- Packed corpuscles volume (P.C.V.).

\section{Results}

The results of the effect of benzene on blood parameters of the male mice in the first stage are summarized in table (1). These results showed a significant reduction $(\mathbf{p}<0.01)$ in red blood corpuscles and white blood corpuscles numbers in all treated groups with benzene compared with the control group. The Hemoglobin concentration was reduced significantly $(p<0.01)$ in the first, the second, the third and the fourth treated groups. The packed cell volume showed also a significant decrease at $(p<0.01)$ in the first group which was treated with $0.2 \mathrm{ml} / \mathrm{kg}$ super benzene ,but this reduction was nonsignificant in the other treated groups.

The results of the effect of benzene on blood parameters of the male mice in the second stage are presented in table (2). The administration of 0.2 and 0.1 $\mathrm{ml} / \mathrm{kg}$ super benzene and $0.1 \mathrm{ml} / \mathrm{kg}$ ordinary benzene caused a significant decline $(p<0.01)$ in R.B.C., W.B.C. numbers and $\mathbf{H b}$.

P.C.V. showed a non- significant reduction in all treated compared with the control group. 
After 90 days of the male mice treated with super and ordinary benzene [Third stage ], the results indicate little or no/effect for benzene on R.B.C. , W.B.C. count, Hb. concentration and P.C.V. [ see table 3 ].

Table(1):-Effect of benzene on blood parameters of the male mice (First stage $)(n=10)$.

\begin{tabular}{|c|c|c|c|c|c|}
\hline \multirow{2}{*}{\multicolumn{2}{|c|}{ Treatments }} & \multicolumn{4}{|c|}{ Blood parameters (Mean+-S.E.) } \\
\hline & & R.B.C. & W.B.C & $\mathrm{Hb}$. & P.C.V. \\
\hline \multicolumn{2}{|c|}{$\begin{array}{l}\text { Control group } \\
\text { Treated with } \\
(0.9 \% \mathrm{NaCl})\end{array}$} & $\begin{array}{l}5634000 \\
+115657 \\
-\end{array}$ & $\begin{aligned} & 7440 \\
&+ 103.49 \\
&-\end{aligned}$ & $\begin{array}{l}12.40 \\
+0.14 \\
-\end{array}$ & $\begin{array}{l}37.90 \\
+0.62 \\
-\end{array}$ \\
\hline \multicolumn{2}{|c|}{$\begin{array}{l}\text { First treated group } \\
\text { With } 0.2 \mathrm{ml} / \mathrm{kg} \\
\text { Super benzene }\end{array}$} & $\begin{array}{l}4072000^{*} \\
+40216 \\
-\end{array}$ & $\begin{array}{l}5225^{*} \\
+65.31 \\
-\end{array}$ & $\begin{array}{l}10.85^{*} \\
+\cdot 18 \\
-\end{array}$ & $\begin{array}{l}27.40^{* *} \\
+1.92 \\
-\end{array}$ \\
\hline \multicolumn{2}{|c|}{$\begin{array}{l}\text { Second treated } \\
\text { group with } 0.1 \\
\text { ml/kg super } \\
\text { benzene }\end{array}$} & $\begin{array}{c}4050000^{*} \\
+-69888\end{array}$ & $\begin{array}{l}5925^{*} \\
+132.75 \\
-\end{array}$ & $\begin{array}{l}11.80^{*} \\
+0.3 \\
-\end{array}$ & $\begin{array}{l}36.00 \\
+0.73 \\
-\end{array}$ \\
\hline \multicolumn{2}{|c|}{$\begin{array}{l}\text { Third treated } \\
\text { group with } 0.2 \\
\text { ml/kg ordinary } \\
\text { benzene }\end{array}$} & $\begin{array}{l}4280000^{*} \\
+81034 \\
-\end{array}$ & $\begin{aligned} & 5625^{*} \\
+ & 192.93 \\
- & \end{aligned}$ & $\begin{array}{l}11.30^{*} \\
+0.28 \\
-\end{array}$ & $\begin{array}{l}32.50 \\
+1.27 \\
-\end{array}$ \\
\hline \multicolumn{2}{|c|}{$\begin{array}{l}\text { Fourth treated } \\
\text { group with } 0.1 \\
\text { ml/kg ordinary } \\
\text { benzene }\end{array}$} & $\begin{array}{l}4560000^{*} \\
+47923 \\
-\end{array}$ & $\begin{aligned} & 6750^{*} \\
&+ 271.31 \\
&-\end{aligned}$ & $\begin{array}{l}11.70^{*} \\
+0.23 \\
-\end{array}$ & $\begin{array}{l}35.40 \\
+0.24 \\
-\end{array}$ \\
\hline \multirow{2}{*}{$\begin{array}{l}\text { L.S.D } \\
\text { value }\end{array}$} & $\mathrm{P}<0.01$ & 463089 & 555.639 & 0.519 & 13.057 \\
\hline & $\mathrm{P}<0.05$ & 327507 & 392.960 & 0.367 & 9.234 \\
\hline
\end{tabular}

*There is a significant difference compared with the control group at $\mathbf{p}<0.01$.

**There is a significant difference compared with the control group at $\mathbf{p}<0.05$.
Table(2):-Effect of benzene on blood parameters of the male mice (Second stage) $(n=10)$.

\begin{tabular}{|c|c|c|c|c|c|}
\hline \multirow{2}{*}{\multicolumn{2}{|c|}{ Treatuments }} & \multicolumn{4}{|c|}{ Blood paraneters (Meau'-S E) } \\
\hline & & R.B.C. & WBC. & $\mathrm{Hb}$. & P.CV, \\
\hline \multirow{3}{*}{\multicolumn{2}{|c|}{$\begin{array}{l}\text { Coufrol group } \\
\text { Treated wifh } \\
(0.9 \% \mathrm{NaCl})\end{array}$}} & 8945000 & 8680 & 14.19 & 38.20 \\
\hline & & +33837 & +56.68 & +0.18 & +0.61 \\
\hline & & . & $\cdot$ & - & - \\
\hline \multirow{3}{*}{\multicolumn{2}{|c|}{$\begin{array}{l}\text { First treated groeup } \\
\text { With } 0.2 \mathrm{malkg} \\
\text { Styper beazene }\end{array}$}} & $5920000^{7}$ & $7545 \%$ & $11.00^{*}$ & 29.80 \\
\hline & & $+1216+6$ & +50.13 & +0.17 & $+0,38$ \\
\hline & & - & + & . & 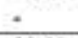 \\
\hline \multirow{3}{*}{\multicolumn{2}{|c|}{$\begin{array}{l}\text { Second treated } \\
\text { group wath } 0.1 \\
\text { mllkg super benzene }\end{array}$}} & $739+4000^{*}$ & $7925^{*}$ & $13.28^{*}$ & 30.20 \\
\hline & & +233965 & +31.13 & +0.23 & +103 \\
\hline & & 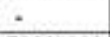 & - & . & - \\
\hline \multirow{3}{*}{\multicolumn{2}{|c|}{$\begin{array}{l}\text { Thid teated growp } \\
\text { with } 0.2 \mathrm{mikg} \\
\text { ordanary beazene }\end{array}$}} & $7355000^{\circ}$ & $7925 \%$ & ${ }^{7} 12.75$ & 30.90 \\
\hline & & +27335 & +50.13 & +0.27 & $+0,18$ \\
\hline & & . & - & 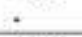 & - \\
\hline \multirow{3}{*}{\multicolumn{2}{|c|}{$\begin{array}{l}\text { Fouth teated group } \\
\text { with } 0.1 \mathrm{ml} / \mathrm{kg} \\
\text { odenary beazene }\end{array}$}} & 8623000 & 7370 & 13.65 & 34.10 \\
\hline & & +29580 & +35.63 & +0.21 & +0.09 \\
\hline & & $\cdot$ & - & $\cdot$ & - \\
\hline \multirow{2}{*}{$\begin{array}{l}\text { L.S.D } \\
\text { value }\end{array}$} & P.001 & 463089 & 555.639 & 0.519 & 13057 \\
\hline & $\mathrm{P}<005$ & $32750^{\circ}$ & 392.960 & 0,367 & 9,234 \\
\hline
\end{tabular}

*There is a significant difference compared with the control group at $\mathbf{p}<\mathbf{0 . 0 1}$.

Table(3):-Effect of benzene on blood parameters of the male mice (Third stage $)(n=10)$.

\begin{tabular}{|c|c|c|c|c|c|}
\hline \multirow{2}{*}{\multicolumn{2}{|c|}{ Treatments }} & \multicolumn{4}{|c|}{ Blood parameters (Me ant-SE) } \\
\hline & & KBC & WEC & $\mathrm{Ab}$ & PCV. \\
\hline \multicolumn{2}{|c|}{$\begin{array}{l}\text { Control group } \\
\text { Treated with } \\
\text { (0.9\% NaCl) }\end{array}$} & $\begin{array}{r}5620000 \\
+29789 \\
-\end{array}$ & $\begin{array}{r}5305 \\
+3685 \\
\end{array}$ & $\begin{array}{l}13.85 \\
+0.06 \\
-\end{array}$ & $\begin{array}{r}37.0 \\
+0.42 \\
\end{array}$ \\
\hline \multirow{3}{*}{\multicolumn{2}{|c|}{$\begin{array}{l}\text { First treated grolp } \\
\text { With } 0.2 \mathrm{mlkg} \\
\text { Super benzent }\end{array}$}} & 5344000 & 5400 & 1347 & 370 \\
\hline & & +246433 & +73.02 & +0.19 & +0.76 \\
\hline & & - & - & - & + \\
\hline \multicolumn{2}{|c|}{$\begin{array}{l}\text { Secoed treated } \\
\text { group with } 0.1 \\
\text { mllkg super benzene }\end{array}$} & $\begin{array}{r}5718000 \\
+180854 \\
\end{array}$ & $\begin{array}{r}5520 \\
+5120 \\
-\end{array}$ & $\begin{array}{r}1308 \\
+0.12 \\
+\end{array}$ & $\begin{array}{r}33.7 \\
+0.36 \\
\end{array}$ \\
\hline \multicolumn{2}{|c|}{$\begin{array}{l}\text { Thurd treated group } \\
\text { with } 0.2 \mathrm{mlkg} \\
\text { ocdinary benzene }\end{array}$} & $\begin{array}{r}5185000 \\
+48562 \\
\end{array}$ & $\begin{array}{r}5105 \\
+39.75 \\
\end{array}$ & $\begin{array}{l}13.15 \\
+0.13 \\
\end{array}$ & $\begin{array}{r}379 \\
+0.67 \\
\end{array}$ \\
\hline \multicolumn{2}{|c|}{$\begin{array}{l}\text { Fourth treated group } \\
\text { wth } 01 \mathrm{milkg} \\
\text { ordinary benztse }\end{array}$} & $\begin{array}{l}5480000 \\
+128711 \\
\end{array}$ & $\begin{array}{l}5920 \\
+61.10 \\
-\end{array}$ & $\begin{array}{r}13.50 \\
+0.18 \\
-\end{array}$ & $\begin{array}{r}38.0 \\
+0.44 \\
-\end{array}$ \\
\hline \multirow{2}{*}{$\begin{array}{l}\text { L.SD } \\
\text { value }\end{array}$} & $P \subset 0.01$ & 463089 & 555.639 & 0519 & 13.057 \\
\hline & $\mathrm{P}=0.05$ & 327507 & 392960 & 0.367 & 9.234 \\
\hline
\end{tabular}




\section{Discussion}

The results of the effect of benzene on blood parameters of the male mice which was measured in the present study indicate a reduction of all blood parameters (R.B.C., W.B.C. , Hb. concentration and P.C.V.) as a result of bone marrow suppression due to a dramatic suppression of the cycling fraction of hemopoietic progenitor cells (Yoon et al.,2001).

The bone marrow is a complex matrix harboring stem cells of blood cells, and stromal cells, which provide growth factors necessary for the proliferation and differentiation of stem and progenitor cells (Tavassoli \& Frieidenstein ,1983 ). The stromal macrophage, regulator of hematopoiesis (Bagby,1987) has been proposed that bone marrow is a specific target of benzene (Kalf et al., 1989).

The results of our study could be explained by the findings of Laskin et al. (1989) and Witz et al. (1996) who suggested that toxic doses of benzene activate bone marrow macrophages and granulocytes, which ,on the one hand release toxic oxygen species responsible for bone-marrow cell killing. On the other hand activated phagocytes can also produce elevated levels of immune mediators and cytokines including interleukin -1 , which may contribute to benzene hematotoxicity by altering the proliferation of subpopulations of bone marrow cells . In addition to toxic oxygen species, Laskin et al. (1995) demonstrated that bone marrow leukocytes from mice administered hematotoxic doses of benzene or the metabolism hydroquinone, pbenzoquinone and $1,2,4$, benzentriol,produced an increased amount of nitric oxide (NO) in response to the inflammatory mediators lipopolysaccharide (LPS) or interferon gamma (IFN-gamma).The production of (NO) induced by the inflammatory mediators was further enhanced by granulocyte -macrophage- and macrophage colony-stimulating factors ,which are the growth factors present in the bone marrow that are required for normal cell proliferation and differentiation. The authors suggested that elevated (NO) production in the bone marrow may be an important mediator of benzene induced bone marrow suppression.

The reduction of blood parameters on our study correspond with the results reported by many studies,for example,Snyder et al. (1980), Cronkite(1986),Cronkite et al. (1989) and Farris et al .(1997).These studies found that the exposure of mice to benzene severely reduces the number of hemopoietic and lymphoid cells in the peripheral blood by inhibition DNA synthesis in progenitor cells in the bone marrow .

The results of the our study indicated that the effect of super and ordinary benzene on blood parameters of male mice was little in the second stage compared with the first stage, while this effect was very little or even absent in the third stage compared with the first stage. These changes occurred when the benzene administration was stopped, therefore the suppression of bone marrow was reversed rapidly and the bone marrow cellularity and committed hematopoietic progenitor content were regenerated to normal or subnormal values(Abraham,1996).The reduction of the benzene effects after benzene administration stopping to the male mice in our study is similar to other studies. Lee et al. (1988) shows that benzene induced suppression of 
hemopoietic progenitor cell cycling is reversed immediately upon stopping benzene exposure.

\section{References:}

-Abraham, N.G.(1996). Hematopoietic effects of benzene inhalation assessed by long-term bone marrow culture. Environ. Health Prespect., 104:1-8.

- Alleva,J.J.;Waleski,M.V.;Alleva,F.R.; et al. (1968). Synchronising effect of photoperiodicity on ovulation in hamster. Endocriniology,82:1227-1235.

-ASTDR.(1991). Toxicological profile for benzene. Atlanta , Georgia, Agency for Toxic Substance and Disease Registry, pp. 193.

-ATSDR.(1997).Toxicological profile for benzene (Update). Public Health Service , U.S. department of health and human services ,Atlanta ,GA. Agency for Toxic Substances and Disease Registry.pp.147.

-Bagby,G.C.(1987).Production of multilineage growth factors by hematopoietic stromal cells:An inter_cellular regulatory network involving mononuclear phagocytes and interleukin-1.Blood cells,13:147-159.

-Baker,F.J.\&Silverton,R.E.(1976).Introduction to medical laboratory technology $5^{\text {th }}$ ed. Butter worths London,pp.733.

-Clark,J.R.\&Kennedy,J.P.(1967). Effect of light and temperature upon gonadal activity in the vole (Microtus agreastis). Gen.Comp.Endocr.,8:474-488.

-Coles,E.H.(1986).Veterinary Clinical Pathology $4^{\text {th }} \quad$ ed. $\quad$ W.B. $\quad$ Saunders Co.Philadelephia,pp.457.

- Cronkite,E.P.(1986). Benzene hematotoxicity and leukemogenesis:Blood cells,12:129137.

- Cronkite,E.P.;Drew,R.T.;Inoue,T.;et al.(1989). Hematotoxicity and carcinogenicity of inhaled benzene . Environ. Health Prespect,82:97-108.

-Deichmann, W.B. , Mac-Donald, W.E. \& Bernal, E.(1963). The hemopoietic tissue toxicity of benzene vapor. Toxicol. Appl. Pharmacol., 5:201-224.

-Farris ,G.M.;Robinson,S.N.;Gaido,K.W.;et al. (1997).Benzene induced hematotoxicity and bone-marrow compensation in B6C3F1 mice.Fundam. Appl. Toxical.,36:119-129.

-Gist,G.L.\&Burg,J.R.(1997).Benzene -a review of the literature from a health effects perspective. Toxicol. Ind. Health,13:661714.

-Goldstein ,B.D. \& Witz, M.D. (2000) . Benzene .In:Lippmann,M. (ed).Environmental Toxicants(Human exposures and their health effects,2/e.).John Wiley \&Sons, Inc.pp.121-149.

-Hays, R.B. , Yin, S.N. , Dosemeci, M. , et al. (1996). Mortality among benzene exposed worker in China. Environ. Health Prespect., 104(6) : 1349-1352.

-Hough, H. \& Freeman, S. (1944). Relative toxicity of commercial benzene and a mixture of benzene, toluene and xylene. Fed.Proc.Fed.Am.Soc.Exp.Biol.,3:20.

-Jawad,A.H.(1997).Ethological studies in assessing the anti_aggressive effects of some Iraqi medicinal plants in laboratory mice (Mus musculus).Ph.D.Thesis, College of Education ,University of Basrah.

-Kalf, G.S. , Schlosser, M.J. , Renz, J.F. , et al. (1989).Prevention of benzene induced myeltoxicity by non-steroidal antiinflammatory drugs. Environ. Health Prespect. , 82:57-64.

-Laskin,D.L.,MacEchem,L.\&Snyder,R.(1989) Activation of bone marrow phagocytes was following benzene treatment of mice. Environ. Health Prespect.,82:75-79.

-Laskin,J.D.;Rao,N.R.;Punjabi,C.J;et al.(1995). Distinct actions of benzene and its metabolites on nitric oxide production by 
bone marrow leukocytes .J. Leukocyte Biol.,57:422-426.

-Lee, E.W. ，Garner，C.D. \& Johnson, J.T. (1988). A proposed role played by benzene itself in the induction of acute cytopenia: inhibition of DNA synthesis. Res. Commun. Chem. Pathol. Pharmacol., 60:27.

-Marcus, W.L.(1990). Chemical of current interest :benzene .Cancer risk from benzene.Adv. Mod. Environ.Toxicol.,17:127-188.

-Morrison ，R.T.\& Boyd ,R.N.(1966).Benzene, Organic chemistry,Allyn and Bacon, Inc. ,Boston .Massachuetts.U.S.A.

-Perbellini ,L.; Buratti,M. ; Fiorentino , M.; et al.(1999). Matrix interferences in the analysis of benzene in urine. $J$. Chromatography, Part B,724:257-264.

-Ray,D.E.;Roubicek,C.B.\&Hamidi ,M.(1968). Organ and gland weights of rats chronically exposed to 22 degrees and 35 degrees C. Growth ,32:1-12.

-Ross, D.(1996).Metabolic basis of benzene toxicity. Eur.J.Haematol.,57:111-118.

-Sarbourin, P.J. , Chen, B.T. , Lucier, G. , et al. (1987). Effects of dose on the absorption and excretion of $\mathrm{C14}$ benzene administrated orally or by inhalation in rats and mice. Toxicol. Appl. Pharmacol.,87:325-336.

- Sarbourin, P.J , Bechtold, W.E. , Birnbaum, L.S. , et al. (1988). Differences in the metabolism and disposition of inhaled $3 \mathrm{H}$ benzene by $F 344 / N$ rats and B6C3F1 mice. Toxicol. Appl. Pharmacol., 94: 128140.

-Sarbourin, P.J. , Bechtold, W.E. , Griffith, W., et al.(1989). Effect of exposure concentration, exposure rate and route of administration on metabolism of benzene by F344 rats and B6C3F1 mice. Toxicol. Appl. Pharmacol., 99:421-444.
- Sabourin, P.J. Muggenberg, B.A. , Couch, R.C. , et al. (1992). Metabolism of C14 benzene by cynomolgus monkey and chimpanzees. Toxicol. Appl. Pharmacol., 114:277-284.

-Schalm,O.W.;Jain,N.C.\&Carroll,E.J.(1975). Veterinary hematology, $3^{\text {rd }}$ ed.Lea and Febiger,Philadelphia,pp.807.

-Snyder,C.A.;Goldstein,B.D.;Sellakumar ,A.R.;et al.(1980).The inhalation toxicology of benzene :incidence of hematopoeitic neoplasms and hematotoxicity in AKR/J and C57BL/6J mice.Toxicol.Appl.Pharmacol.,54:323329.

-Snyder,R.\& Hedli,C.C.(1996).An overview of benzene metabolism . Environ. Health Prespect.Suppl.,104:1165-1171.

-Tavassoli,M.\&Friedenstein,A.(1983). Hemapiotic stromal microenvironment. Am. J.Hematol.,14:195-203.

-Witz,G.Zhang,Z.\&Goldstein,B.D.(1996). Reaction ring-opened aldehyde metabolites in benzene hematotoxicity . Environ. Health Prespect.,104:1195-1199.

-Yoon,B.;Hirabayashi,Y.;Kawasaki,Y.;et al.(2001).Mechanism of action of benzene toxicity: cell cycle suppression in hematopietic progenitor cells (CFUGM).Experimental Hematology,29:278285.

-Zhang,L.;Lastmond,D.A.\&Smith,M.T.(2002). The nature of chromosomal aberrations detected in humans exposed to benzene .Critical Reviews in Toxicology,32(1):142. 


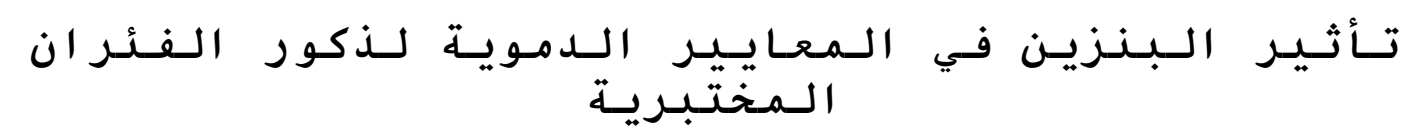

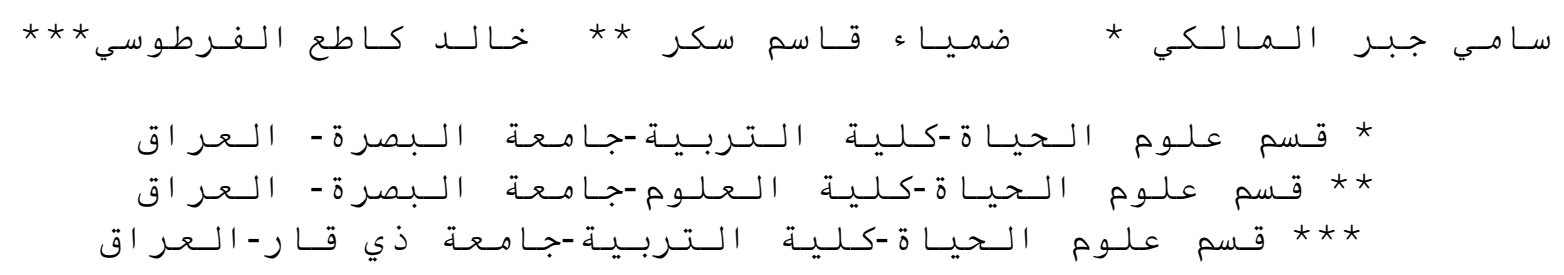

الـبـحث مستل مـن اطروحة دكتـور اه

\section{الخلاصة}

استخدم البنزين المحسن والبنزين العادي لبحث تأثير البنزين في المعسايير الامويــة لـــكور الفئران المختبرية .

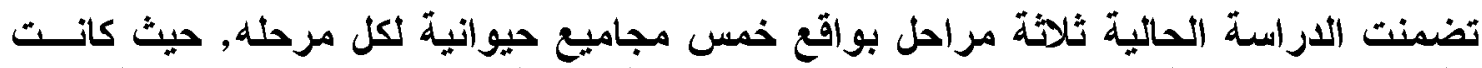

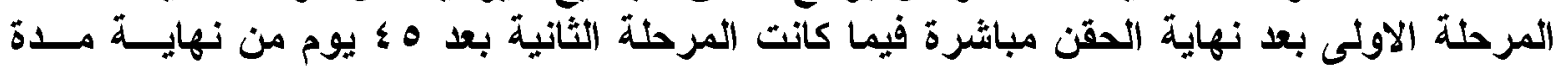

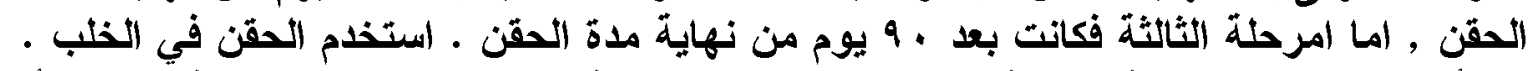

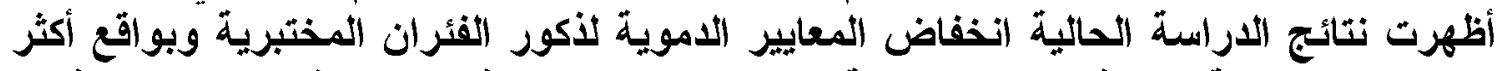

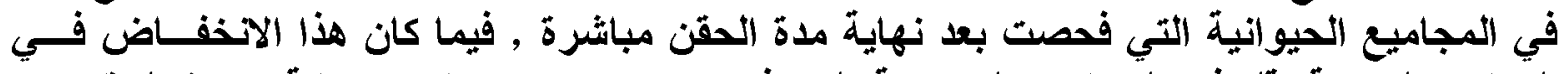

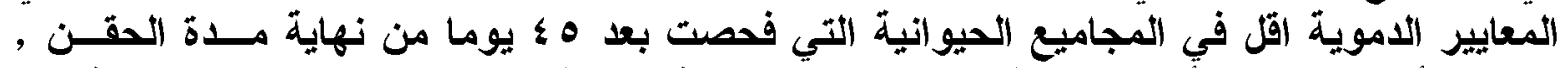

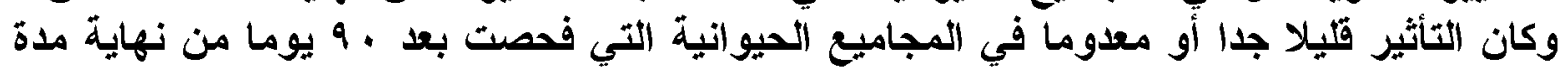

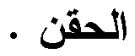

